\title{
Advantage of the Part-time Teacher in Charge in Education Professional Teachers in Colleges and Universities
}

\author{
Jin Zhang \\ The Fashion Management Branch Jiangxi Institute of Fashion Technology Nanchang, China \\ 170243295@qq.com
}

Keywords: Professional teachers; Part-time teachers; Training; Management

\begin{abstract}
With the continuous development of teaching reform, many colleges and universities have participated in the professional teachers as part of the student management model, professional teachers as part-time teachers, responsible for training vocational students learning interest and teaching professional knowledge, Building can play a positive role. Not conflict teaching work under the foundation, play an active role in cultivating the professional quality of students, enhance the ability to enhance the ability to cultivate excellent.
\end{abstract}

\section{Introduction}

According to the development of higher education, the number of students in higher vocational education is increasing year by year. In order to improve the efficiency of student learning management, in recent years, some colleges and universities have applied full-time teacher part-time class teacher management to reform the traditional school management model.

Part-time teachers for the majority of the school work in the more basic work, has become an important part of China's higher education; as a part-time head of this identity, not only in the role of students in the ideological and moral Education and learning in the management of life, but also should reflect the part-time teacher in the student's professional ability education and training on the positive and practical role, but also the healthy growth and guidance of college students.

\section{College Students of the Status Quo Analysis}

College Students Are Adult Groups, not Like the Middle School Students That Model, and Their Active Thinking to Form a Strong Self-characteristic. They will gradually develop their own professionalism and even the outlook on life and values in the university campus. World outlook. At present, the main body of students in vocational colleges is "90" students are very self-selectivity, very few blind obedience command; more willing to express self-consciousness and advocacy, do not accept precepts and rules, but also anti- Like the publicity personality, more independent self, the objective sense of the team and the concept of assistance to people with both less than the exchange of people with the passive and failing sensitive and crisp fall.

How to Deal with the Construction of Style of Study. The direction of learning is not clear there are always some students in the class do not want to learn how to, self-control is poor, the lack of positive attitude and attitude. There is even desperate to think of the parents in the university did not nagging around the nice mixed day, has been late, leave early, absenteeism and other status

Quo ankle, even if it is not afraid to rebuild. This phenomenon is more serious. The use of understanding of the students to help students plan their careers with the expansion of higher education in higher education, the employment trend of students in higher education is becoming more and more serious. The school is very concerned about the employment of students. The background characteristics of each student in the classroom have a certain understanding, choose to provide a certain amount of employment information, training students in the job market to help students find the right work. 


\section{The High School Professional Teachers Part-Time Class Teacher's Ability to Work}

Of the Enrolling Students in School Education. Just entering the university freshmen, most of the learned professionals know nothing or little knowledge may be introduced through the enrollment like this profession. As a professional knowledge of professional teachers part-time class teacher, good for the early new education, can be very accurate in place to the students can introduce the various professional and characteristics, including future employment direction and trends, and according to their professional work experience, many years, And students close to communicate with each other, so that students from professional to unfamiliar preferences to accept, and then they are interested in professional interest in determining the good learning objectives, to correct attitude to learning, into learning motivation.

As Part-Time Class Teacher to Have the Code of Conduct. Colleges and universities have a good quality of teachers and students and service levels, and have the appropriate professional level, while the professional teaching ability can be appreciated by students and follow. Can be very simple to allow students to accept, they combine the work of specialty and professional characteristics of the student behavior and ways of thinking to guide students in learning, life and work, the future employment capacity; slowly a little bit of exercise students learning attitude And self-motivated, but also hone their willpower and attitude of others attitude. Positive spirit and correct attitude towards learning, etc., become a mentor of the students greatly enhance the interaction of students.

Teachers not only to educate students, more to lead by example. Like parents, like children, for students to establish a principle, enterprising, shameless, polite four norms. This will deeply affect the students' thinking and behavior, and students' in-depth exchanges with the students, words and deeds will slowly change some people's misconduct. In-depth exchanges with students, the students' state of mind, more familiar with the ability to accept. For example, many teachers in our school has been fully aware of the many characteristics of college students, changing the traditional teaching methods and methods, the better the transformation of the task-oriented teaching methods, and actively mobilize the enthusiasm of students.

To create difficulties in their exploration process will resort to teachers, teachers in the exploration of the process of exposure to new ideas for students on their own teaching and research work is also of great help, for Enterprise job settings, employment needs and other aspects of the information is also the carp professional teachers to further modify their teaching content design, truly, teacher-student interaction, teaching and learning. And Teachers can also through classroom teaching, the first time students to study the subject of monitoring and norms.

The use of professional knowledge to help teachers learn a reasonable choice of jobs. The achievements of a number of advantages: First of all, professional teachers are very aware of the professional employment trends, market demand for talent, job positioning functions, etc., as a professional teacher of all professional familiar with the course, as the class teacher for each student's own ability and level Have a certain right to speak, the perfect combination of the two really play a good teacher to guide students in the employment trend of development; the second point of the students of the sixth semester of enterprise practice, as a professional teacher is also fully demonstrate their strengths to guide students to understand the employment situation facing And how to adapt to the current stage of self-demand for talent; the third point how to help students change roles, how to adapt to internships and adapt to the practice environment, and professional teachers also have more information and recommend the ability to recommend excellent students To the appropriate and better employer, for the construction of a platform for talents.

\section{Professional Teachers as the Class Teacher by the Thorny Few Problems}

1. To deal with the contradiction between the appropriate students and professional teaching work, part-time teacher is a special group of multiple roles, some teachers in teaching and research work there is a certain lag, the commitment to the work of the lack of class initiative, Some teachers still belong to the perfunctory line; and some teachers in the teaching work and work in the work did not 
coordinate well in place, has been delayed the work of the results, it is distressing. School and branch leaders to take these issues seriously, if not to find the appropriate approach, then our professional teachers part-time work will be greatly restricted.

2. How to reasonably arrange the task of teaching, student work tasks and daily work time is now part-time college teacher need to solve a problem. Many professional teacher part-time teachers because of heavy teaching and research tasks, the class management is difficult to do everything. And as part-time teachers are mostly middle-aged teachers, not only the pressure of professional work, as well as the responsibility of family children, energy and time is one of the biggest problems. If not very good coordination of this contradiction, it is difficult to enhance the work of teachers' motivation and enthusiasm.

3. How to measure the role of a good teacher and professional teacher position is very important to fully reflect the work efficiency of a state. Although the school will be based on the different nature of the work of the corresponding development of the corresponding manual, but the specific work is often in the work processing prone to blending, fuzzy work status. Therefore, regardless of the need for teaching management in any form of teaching work requires multi-party communication and coordination, mutual support and cooperation with each other in order to further closer the task of dealing with the various tasks and the purpose of personnel training.

\section{The Advantages of Professional Teachers as the Class Teacher}

The Use of Freshmen into the Education, Students Develop Professional Interest in Learning. Students before admission, the professional situation is not very understanding, more difficult to talk to establish a professional ideal. As a professional teacher can use their own professional advantages, explain the status of the profession and development trends, the employment of students in previous professional students and other topics of concern to help students understand the professional learning of the content and social needs, Establish a professional ideal, so that students from the beginning of the entrance to the study and professional ideals combine to formulate scientific learning objectives and plans so that students in the beginning of their own future employment have accurate positioning.

The Use of Teaching Sessions, to Promote the Construction of Class Good Style of Study. Professional teacher as a teacher is conducive to the construction of class fine style of study. Students due to the class teacher's face will not easily absent without reason, and because the teacher and other professional teachers are more familiar with, easy to understand the performance of students in other professional courses, to facilitate the learning and thinking of class students understanding and evaluation of excellent The work carried out, is conducive to urge students to complete the task of learning and professional training in the sense of innovation, and promote the formation of excellent class style of study.

The Use of Daily Teaching, to Enhance the Professional Quality of Students. The education of professional teachers is mainly through professional knowledge and skills to achieve the transfer, students receive professional knowledge at the same time, unwittingly accepted the teachers in the industry doubts about the integration of the moral character, emotion, will, etc. Content, to a certain extent, it can be said that knowledge and skills transfer process objectively become the carrier of teacher education.

The Use of Re-Theory and Practice Teaching the Interaction between Teachers and Students Is Conducive to Teaching and Learning. Ordinary professional teachers, and the students get along relatively little time, it is difficult to truly "know ourselves", in the teaching of the inevitable growth of teaching and learning out of touch phenomenon.

\section{Concluding Remarks}

As a professional teacher as a teacher, I will continue to explore in the future work practice, and constantly improve their professional skills and ideological cultivation, lead by example, willing to give full play to the application of class teacher in the cultivation of the important role, College 
students and make a greater contribution to the output.

\section{References}

[1] Xingzhou He, Ying Chen, Yaying Shen. New media perspective of college class teacher information literacy [J]. Journal of Zhejiang University of Technology (Social Science) .2014 (01)

[2] Huarong kuang, Xiaoli Wang. Part-time class teacher work practice thinking [J]. Science and Technology Information .2011 (21)

[3] Qiong Shi,Xiang Li ,Yinhua gu. On how to play a part-time professional teachers in university style of study in the role of 〔J $〕$. Science and Technology Information, 2011 (09).

[4] Junlei Dong .Practice and thinking of part-time teachers in colleges and universities [J].Journal of Beijing Electric Power Academy, 2010 (09).

[5] Junping Huang, Chuan Yang, vocational college teachers' professional specialty analysis [J]. Vocational Education Research. 2010 (10)

[6] Bo Shen, the new era of college class management and the work of the class teacher to explore [J]. Knowledge Economy .2015 (10)

[7] Lingzhi Li, a little talk about the work of class teacher [J]. Anhui literature (second half) .2014 (04)

[8] Ya Long. Talk about the importance of ideological education in colleges and universities in the teacher in charge work [J]. Journal of mudanjiang Education College. 2016 (7)

[9] Yuqiang Song, Wanqun Huang, Ming Zhao .The practice and thinking of class teacher's work in the new period [J]. Education and Teaching Forum 2013 (49)

[10] Taildyan Tuer muddy, the importance of the teacher in charge in university students' employment guidance work [J]. Journal of management. 2016 (23)

[11]The school's style of study in the role of [J]. Science and Technology Information, 2011 (09). 